\title{
Does the Motivation for Market-Based Reform Matter? The Case of Responsibility Centered Management
}

\author{
Amanda Rutherford \\ School of Public and Environmental Affairs \\ Indiana University \\ 1315 E Tenth Street \\ Bloomington, IN 47405 \\ aruther@indiana.edu \\ Thomas Rabovsky \\ School of Public and Environmental Affairs \\ Indiana University \\ 1315 E Tenth Street \\ Bloomington, IN 47405 \\ rabovsky@indiana.edu
}

Amanda Rutherford is assistant professor in the School of Public and Environmental Affairs at Indiana University, Bloomington. Her research focuses on performance accountability systems, executive profiles and decision-making processes, and representative bureaucracy.

Thomas Rabovsky is assistant professor in the School of Public and Environmental Affairs at Indiana University, Bloomington. His research focuses on accountability performance management, managerial values and decision making, and higher education policy. 


\title{
Does the Motivation for Market-Based Reform Matter? The Case of Responsibility Centered Management
}

\begin{abstract}
Organizational theorists have long examined the implications of market-oriented policies for public agencies. Current research often aims to understand the effects of policies imposed on organizations by external stakeholder groups, and few have attempted to gain a better understanding what mechanisms cause agencies to select into these strategies. The purpose of this study is to understand, first, which factors make an organization more likely to adopt a decentralized, market-based budgeting system termed responsibility centered management $(\mathrm{RCM})$ and, second, whether this type of system has implications for organizational performance. Using data on doctoral granting public and private nonprofit four-year universities in the United States, we find that mission, resource dependency, and state party control influence the take-up of RCM. In terms of effects, RCM creates winners for graduation rates (white students) and degree production (science, technology, engineering, and math or STEM departments), which raises potential questions of equity across groups.
\end{abstract}

Acknowledgements: The authors would like to thank Daniel Lopez and Julio Zambrano-Gutierrez for their help in the data collection process. 


\section{Practitioner Points}

- Responsibility centered management (RCM) has grown in popularity over the last decade and has been touted as a way to improve cost-efficiency, innovation, and performance of large organizations such as universities.

- Universities that are both highly reliant on state financial resources and in states with a high share of Republican legislators are more likely to adopt this reform.

- RCM increases degree production in STEM fields but has no effect on the production of humanities degrees.

- While RCM appears to increase graduation rates, the increase is driven by white graduation rates with little change in graduation rates for minority students, which may be due to the underrepresentation of these students in STEM fields. 
Recent decades have seen a decline in public trust in government, much of which has been fueled by the idea that the bureaucracy as a whole is unwieldy and inefficient. Policymakers have often subscribed to the notion that market-oriented reforms and the restructuring of incentives for public agencies will result in administrative outcomes that are both higher in quality and a more effective use of resources. The assumptions embedded in this perspective have been examined and contested in multiple contexts such that many groups of scholars have voiced doubts about the appropriateness of reforms centered on principles related to decentralization and marketization, perhaps most recently through ideals espoused by New Public Management and outcomes-based performance regimes (Bevan and Hood 2006; Hillman, Tandberg, and Fryar 2015). While studies on the effectiveness of such policies have generated valuable research that aides in theory building for understanding externally imposed reforms, there are also cases in which organizations voluntarily opt into changes that extend from marketbased approaches to management. Empirical research examining questions of decision making processes (Nielsen 2014; Rabovsky 2014), innovation (Damanpour, Walker, and Avellaneda 2009), or organizational turnaround (Boyne 2004) sometimes touches on internally-initiated processes but often does not separate such processes from cases of externally imposed change. ${ }^{1}$ Yet understanding when organizations select into market-based strategies and what the consequences are of such change can increase our understanding of what mechanisms motivate managers to adopt these strategies in an era of accountability as well as whether this type of change is any more or less promising for organizational performance than the juggling of incentives designed by political principals.

This study focuses, first, on identifying the mechanisms related to the adoption of responsibility centered management $(\mathrm{RCM})$ and, second, the implications of adopting RCM for 
organizational performance in the context of U.S. institutions of higher education. RCM, also referred to as responsibility based management, responsibility centered budgeting, and revenue responsibility budgeting (Strauss, Curry, and Whalen 1996), can be described as a decentralized budget structure in which individual units within an organization are tasked with bringing in their own revenue to support their own expenditures. These decentralized processes attempt to emulate private sector models that allow successful branches of an organization to grow while weak units may be reorganized or dropped entirely. U.S. postsecondary education presents an optimal policy area in which to study internally adopted market-based approaches given that these organizations have seen a drastic decline in support from the public at-large and have been faced with expanding performance accountability policies developed by state and federal level policymakers. The saliency of accountability in this sector resembles a trend present in many other sectors, including health, welfare, and corrections. Findings in one sector may, of course, face limits in generalizability to other sectors but can provide a step forward for expanding research and encouraging replication across policy areas.

In the following sections, we first consider the differences in motivation for externally imposed and internally initiated organizational change in an era of market-oriented reforms and shifts towards the privatization of services in many public agencies. After specifying hypotheses for the causes and effects of RCM adoption, we employ Cox proportional hazards models and two-way fixed effects models to examine our hypotheses in the context of four year institutions of higher education in the United States. We find that resource dependency, organizational size, and whether an institution operates a hospital or medical center are associated with a higher likelihood of RCM adoption. As expected, politics also matters; higher shares of Republican legislators in a state raise the likelihood of adoption of RCM for those institutions that are more 
reliant on state appropriations. Most importantly, the effects of RCM reveal relationships that raise interesting questions of equity. RCM structures are associated with an overall rise in student graduation rates. However, when examined more closely, white students benefit while traditionally underrepresented student do not gain or lose. Similarly, while RCM is associated with more STEM degrees conferred per 1,000 students, humanities degrees, which are often viewed as the programs that might experience decline under RCM strategies, neither gain nor lose. Following the presentation of these findings, we discuss the implications of this study and pose ways in which to examine similar self-initiated internal changes in other organizational contexts to determine the generalizability of the relationships detected in this dataset.

\section{Externally Imposed vs. Internal Adoption of Market Forces in Organizations}

Discussion of decentralized organizational structures and an increased presence of accountability measures to improve the efficiency of public organizations is not new. Work by Simon (1946), Kaufman (1969), and Hart (1972), for example, are illustrative of questions about the proper measurement of decentralization and whether the benefits of decentralization outweigh the drawbacks of such organization in an agency. Further, conversations about the role of politics in administration and whether bureaucrats should be value-neutral (e.g., Rourke 1992) stem back to some of the earliest debates in the field of public administration.

Attention given to specific reforms and accountability has varied over time. Most recently, the introduction of New Public Management (NPM) in the latter portion of the twentieth century and the expansion of better data sources generated a growing body of research focused on understanding the implications of market-based performance accountability policies imposed by externally-located political principals on public organizations (Pollitt 2002; Walker, Damanpour, and Devece 2011). Supporters of NPM policies and concepts of reinventing 
government have championed changes in organizational structures and incentives that are argued to better allow managers to manage (Moynihan 2008); these include decentralization in decision making processes, accountability for organizational outputs over processes, and higher levels of competition among organizations for resources (Rutherford and Rabovsky 2014). Essentially, the focus on procedural control is lessened to encourage creativity and entrepreneurship while performance measurement holds organizations and managers accountable for producing some identified level of optimal output (Radin 2006; Van Dooren 2008).

Much of the modern research on reforms based on ideas of marketization and performance assessment finds that the effects of such policies are negligible at best and detrimental at worst. Causes for such ineffective policies include but are not limited to dysfunctional behavior due to poorly structured incentives (Bohte and Meier 2000; Radin 2006), failure to increase autonomy over process while raising expectations for outputs (Brudney, Hebert, and Wright 1999), and the inability to measure performance and use information in a meaningful way (Moynihan and Pandey 2010). At the center of these discussions are debates about whether multiple assumptions - that the goals of organizations can be identified, that such goals can be measured, and that organizational actors know how to achieve these goals if incentivized correctly—have any validity (Rutherford 2014; Speklé and Verbeeten 2014). Evidence of the fallacies in these assumptions abounds in public administration and political science literature, further raising doubts about whether externally created performance accountability policies can find any meaningful success when linked to policy outcomes such that the benefits of implementing these changes are greater than the costs (for example, Andrews and Hill 2003, Schick 2001). 
While empirical research on market-oriented reforms continues to grow, less attention has focused on determining why organizations opt into market-based strategies internally or what the implications of such decisions might be for performance (but see de Lancer Julnes and Holzer 2001; Walker, Damanpour, and Devece 2011). Research in this area has focused on innovation and strategic change in a more general sense. Often, these studies discuss innovation through collaborative efforts or focus on changes that relate to theories of resource dependency and contingency (e.g., Damanpour, Walker, and Avellaneda 2009). Additionally, research on organizational turnaround considers internal strategies of reorganization, retrenchment, and repositioning (Boyne 2004). Yet, much of this work on innovation, change, and turnaround does not explicitly focus on market-based strategies in which organizations are competing against one another for resources and clientele.

Internal market-like strategies could differ from externally designed accountability reforms for at least three reasons related to stages of the policy process (Nakamura 1987) and the development of organizational change (Fernandez and Rainey 2006). First, the motivation for the change in policies can be vastly different. For instance, Behn (2002), in a discussion of why not all public managers are adopting performance management, identifies challenges as practical, political, managerial, and psychological. Some of these challenges-especially those related to principal-agent relationships — could lessen if such change is adopted internally. Instead of responding to external stakeholders who can choose the extent to which organizational actors are included in decisions about how a policy is shaped, actors within the organization can offer their own ideas, insight, and expertise as the policy is developed. If top-level managers determine that the policy will not work, then they are not obligated to continue using it, at least in the same way they would be due to some external piece of legislation or related mandate. 
This links to a second difference situated around another piece of the policy processimplementation. If it is the case that actors internal to the organization have set their own agenda and defined many of the terms of a market-based strategy, then there is likely to be significantly higher levels of personnel buy-in and, subsequently, greater fidelity during implementation. Whereas actors may only marginally implement externally created policies or find ways to skirt around such policies, they may be more likely to commit to the implementation of internally created strategies (see additional contextual information in Fernandez and Pitts 2007, Fernandez and Rainey 2006). Additionally, some scholars have argued that, for a variety of reasons, public managers have strong incentives to care deeply about organizational performance and client outcomes (Moynihan 2008). As a result, when these actors decide to pursue new reforms and strategies, they are much more likely to do so in ways that generate substantive improvement and productive change - at least when there is a credible connection between the reform and performance - as compared to externally imposed policies that are often dysfunctional or viewed as purely symbolic.

Finally, how performance is defined and measured is likely to vary between external policies with many stakeholder groups versus internal policies in which bureaucrats with higher levels of expertise and experience have a louder voice (Poister 2003; van Thiel and Leeuw 2002). Public organizations are generally seen as having multiple goals that create ambiguity and competing priorities. These complexities are often cited as generating some opportunity for misreporting, cream-skimming, and other types of perverse behaviors (Radin 2006) when policymakers create performance definitions that do not reflect the actual mission of the organization. If internally created measures can be assumed to be more appropriate definitions of performance ${ }^{2}$ that can increase buy-in by others along various levels in the organization, then 
it is possible that such market-based changes can generate improvement in organizational outputs. If these differences are not experienced, internal initiatives may fall to the same obstacles as those policies generated in the external environment.

\section{Mechanisms that Drive the Adoption of Market-Based Strategies in}

\section{Organizations}

What might drive organizations to bring market-based principals into their organizations in an attempt to maximize performance? First, we argue that the presence of policymakers with right-leaning ideologies will encourage the adoption of market-based policies within organizations. Republican policymakers are often seen as suspicious of large government, and in recent years have been associated with a variety of efforts to reduce spending and privatize higher education (Morphew and Eckel 2009). When more Republicans are in office, organizations may receive additional pressure to adopt internal reforms that signal a willingness to incorporate strategies that are consistent with market-based reforms. Additionally, organizations may feel similar pressures when state policymakers adopt other market-based accountability policies, such as performance based funding, which has often been associated with these efforts in higher education (McLendon, Hearn, and Deaton 2006). In other words, the presence of external outcomes-funding measures may push organizations to adopt this style within the organization as well. While this has the potential to blur the lines of whether such reforms are adopted by organizations in a voluntary fashion, this phenomenon is still different from the direct imposition of a policy from actors outside of the organization.

H1A: The higher the share of Republicans in the state legislature, the more likely an organization will be to adopt market-based strategies. Similarly, organizations in states with a Republican governor will be more likely to adopt market-based strategies. 
H1B: Institutions in states with performance funding policies for higher education will be more likely to adopted market-based strategies.

Second, we argue that the lower the level of dependency on government resources, the more likely an organization will be to adopt a market-based strategy to bolster performance. Many agencies have pursued non-governmental sources of revenue or other types of resources, especially in the wake of the recent economic depression; the case of higher education in this study is a prime exemplar of such behavior (for example, Mitchell, Palacios, and Leachman 2014). When shifting resource dependencies create a higher level of competition among multiple agencies, these organizations will become embedded in a market that reflects some characteristics of private firms. In order to survive in such markets, one potentially useful tactic could be to adopt strategies focused on market-based incentives within the organization. In other words, the drive to find other resources will not only be a goal of central administrators but will also be decentralized to subunits throughout the agency.

H2: The lower the level of dependency on government resources, the higher the likelihood of RCM adoption.

\section{Potential Implications of Market-Based Strategies Adopted by Organizations}

Understanding whether market-based policies, once adopted by an agency, will have any measurable effect on performance is arguably more important than understanding the causes, as policy outcomes could have positive or negative consequences for stakeholder and clientele groups. Given the similarity of these policies to externally-constructed market-based approaches, it might be reasonable to expect a negative or null effect given the number of studies that find such effects for externally imposed policies (e.g., Soss, Fording, and Schram 2011; van 
Thiel and Leeuw 2002). However, the differences in how such policies are shaped within the organization could lead to a positive effect on performance if these differences create more meaningful policies. Thus, the effect on performance is a function of both (1) the validity of market-based principles in public or semi-public agencies and (2) the motivation that can generate voluntary internal changes in an organization.

If the source of the policy (internal vs. external) matters less than how market-based strategies affect public or quasi-public organizations, then it is quite feasible that these policies will negatively affect organizational performance. This assumes that, first, market-based strategies will have a negative effect as based on recent research that suggests many limitations for this approach and, second, that this market influence will outweigh any benefit from the internal source of the change. On the other hand, it may be that the source of change matters more than the type of policy implemented. In this case, the differences throughout the policy making process - the motivation for agenda setting, definitions of performance in defining policies, and buy-in that encourages implementation (see Sabatier and Weible 2014)—can lead to gains in performance under such systems, all else equal. If such a change is internally adopted and means that the organization has greater buy-in to the change (at least compared to an externally imposed policy), then employees throughout the organization may work to successfully implement the policy rather than look for loopholes or other ways to shirk. If management matters and the policy is meaningful, then higher levels of outputs in the organization should be expected.

H3: The internal adoption of market-based strategies in an organization will be associated with lower levels of organizational performance. 
H4: The internal adoption of market-based strategies in an organization will be associated with higher levels of organizational performance.

There is also a third possibility to consider if overall performance is disaggregated. As mentioned above, common critiques of externally-imposed performance accountability systems argue that incentives can encourage perverse behavior that can artificially increase organizational performance. In other words, implementation occurs such that performance may increase, but the method of performance gains either does not adhere to the intended purpose of the policy or the policy does not correctly consider unintended consequences. Among the most common concerns voiced is that winners and losers will be created (Hearn and Gorbunov 2005; Heinrich 2002). Clientele who need less help but who are easier to target for quickly boosting baseline performance may gain while other service recipients who present more difficult cases might stand to lose, especially through the denial of services. This has perhaps been most recently vocalized in the context of K-12 education, where performance accountability policies have been discussed since the late 1980s (for example, Darling-Hammond 1994, Diamond and Spillane 2004). Research has illustrated that schools can game which students are exempted from standardized tests (Cullen and Reback 2006) and that good schools often get better while poorly performing schools get worse in their attempt to comply with policy demands (Diamond and Spillane 2004). Thus, we might expect that, at the individual level, clientele who appear easy to serve will benefit while more risky clientele will lose. At the organizational level, these systems may provide incentives that allow units that already perform well to grow while those that struggle to hit benchmarks face additional challenges.

H5: The internal adoption of market-based strategies in an organization will be associated with the creation of winners and losers in the organization. 


\section{Responsibility Centered Management in Institutions of U.S. Higher Education}

The focus of this study is on the organizational adoption and implementation of Responsibility Centered Management (RCM). RCM essentially decentralizes decision making processes to specific units within the organization. Units are in charge of maintaining revenues and expenditures with less support from a centralized office (Gayle, Tewarie, and White Jr. 2003). In theory, this can allow managers of each unit to be more entrepreneurial and to pursue strategies that are best for their part of the organization. These concepts - additional autonomy in processes coupled with rewards and sanctions for achieved outcomes—-sound much like the discussion of performance accountability policies considered by policymakers at the local, state, and federal levels.

We examine RCM in the context of U.S. postsecondary education, where the policy has spread since the 1980s. While a moderate number of institutions implemented such systems before the 2008 recession, adoption of RCM has expanded rapidly in the years since the recession, particularly as state appropriations for higher education declined substantially. Of the institutions that have adopted or are considering the adoption of RCM in our sample, over half occur after 2009. Although a wide variety of public and private institutions have adopted RCM, only case studies, largely authored by proponents and previous adopters of RCM, currently exist (Hearn et al. 2006; Whalen 1991; Willett 2013).

Implementation of RCM varies somewhat across institutions, as colleges and universities using an RCM model must make key policy design decisions related to the allocation of both costs and revenues, funding and support for data management systems, and accounting for special or unique administrative arrangements (University of Arizona N.D.). For example, one of the key issues that RCM policies must address is how revenues are allocated to various units as it 
relates to student tuition. One approach is to allocate these funds based on a student's declared major, while another approach is to do so based on credit hours that students take within a given department. Such differences can have important financial implications, especially if some schools or departments offer classes that enroll large numbers of students who are majors in other units on campus. In practice, many universities incorporate a mixed approach, where a portion of tuition funding is determined by major, and a portion is determined by credit. The University of Michigan, for instance, gradually transitioned from a model where tuition revenue was determined by a student's major to one where funding was equally divided according to both major and credit hour, whereas Ohio State University uses a more nuanced system that incorporates two-year averages based on credit hours and that varies how this revenue is allocated based on 14 categories of course/level of student (University of Arizona N.D.).

Another important element that varies somewhat across institutions relates to cost allocation, particularly in defining costs that are specific to a unit versus costs that are shared across units. The latter category often means there will be some taxes applied to all units that are then used to fund such shared costs or cost pool such as administration, facilities, and IT. At Iowa State, for example, the university operates seven cost pools, one of which is funded by state appropriations (university leadership). Utilities at the University of Michigan are separately metered and charged to units, and taxes are calculated using a two year lag so that units can more accurately anticipate costs and revenues. Most units at Michigan also receive supplements from the general fund (University of Arizona N.D.). Such decisions are fungible and can create much debate. A 2014 Syracuse faculty senate report, for example, discusses concerns of large taxes but few resources back in assistance (Syracuse University 2014). 
While institutions vary in the specifics of policy design and implementation, RCM policies across institutions share common core elements of decentralized budgeting and increased autonomy at the school/program level, and several benefits of RCM have been cited by advocates of budget reform in higher education. Its objective consists of "clarifying roles and responsibilities between local and central units, linking cause and effect through revenue and indirect cost allocations, placing local academic planning and decision making in a cost/benefit context, and unleashing entrepreneurship" (Strauss and Curry 2002, 3). Further, the decentralized structure can purportedly result in better decision making as the decision maker is closer to relevant information. These decisions can be aided by the facilitation of responsibility for entrepreneurial activities, encouragement of competitive services, and the expression and quantification of central and unit-specific strategic plans (Strauss and Curry 2002; Willett 2013).

Multiple criticisms of RCM have also been raised that share many commonalities with other externally shaped policies such as New Public Management. These include concerns that decisions will be driven by dollar figures rather than by academic quality and rigor, that inappropriate faculty and school behavior may emerge and even be incentivized in some cases, that rich units will get richer, and that local optimization will lead to a weaker whole (Hearn and Gorbunov 2005). Debates on cross-unit disparities and whether the rich gain relative to other units are key for hypotheses 3-5 in this study. Many of the potential issues with RCM are more likely to center on individual attitudes and motivations rather than technical or structural constraints (Gayle, Tewarie, and White Jr. 2003), indicating that the decision to adopt these reforms could face challenges in some organizational units should questions of fairness be raised.

\section{Adoption Patterns of Responsibility Centered Management}


The empirical analysis for this paper proceeds in two parts. The first portion evaluates factors associated with the adoption of RCM while the second evaluates the effect of RCM on institutional performance. Summary statistics for each portion of the analysis are presented in Tables 1 and 2 below. We focus on both public and private research and doctoral institutions as these organizations have been the most prominent adopters of RCM. This approach can control for variation in agency mission between these universities and teaching-oriented colleges.

\section{$<<<$ Insert Tables 1-2 About Here $>>>$}

\section{Key Variables}

To identify whether and when institutions adopted RCM, we employed a variety of approaches. We began by using several published reports on RCM to identify institutions where RCM had previously been documented (Koch, Reynolds, and Rimai 2012; Strauss and Curry 2002). Next, we searched university webpages and other online sources for official documents that mentioned RCM or any related terms (i.e., responsibility based management, responsibility centered budgeting, and revenue responsibility budgeting). We then followed up with institutions where the adoption or timing of RCM implementation was unclear by contacting university staff with knowledge of institutional finances and budgeting practices directly through both phone and email. We coded an institution as having implemented RCM when it began allocating resources on the basis of the reform; we do not count institutions as having adopted RCM when they were still in the planning or development stage. We also recognize that, while we are coding RCM systems as " 0 " or " 1 " here, institutions coded as having RCM may implement slightly different variants of RCM systems; for the purpose of this study, we consider all RCM institutions as a whole. In total, we identified 32 research/doctoral institutions that adopted some identifiable 
type of RCM reform, dating back to 1974 out of 276 total public and private not-for-profit research/doctoral institutions. ${ }^{3}$ Table 3 lists these institutions and the year that RCM took effect. $<<<$ Insert Table 3 About Here $>>>$

Given that RCM is largely based on NPM ideals regarding the decentralization of budgeting and the use of market-like mechanisms to encourage large bureaucratic organizations to better incentivize innovation and entrepreneurship on the part of mid-level managers and employees, we expect that universities located in states that are politically conservative will be more likely to adopt and implement RCM within their own organizations. We use Klarner's dataset on partisan balance in the states (Klarner 2016) to capture the percentage of state legislators who are Republicans and the partisanship of the governor. Organizations in states that have adopted other NPM inspired reforms, specifically performance funding, may also consider the adoption of RCM policies more explicitly. To test hypothesis $1 \mathrm{~B}$, we include a dichotomous variable that is coded as 1 when institutions are subject to a policy that links some portion of their funding to state appropriations and zero otherwise. Given that existing performance funding policies do not affect private four-year institutions, we code all private universities as zero, even if they are located in states with a performance funding policy. States were coded for performance funding policies via a combination of personal contacts with state officials and a report on performance funding by the National Conference of State Legislatures (NCSL 2015).

Our second hypothesis is grounded in resource dependency. In this study, there is a high level of variation in the extent to which universities rely on state governments for support, even within the public sector (McLendon, Mokher, and Doyle 2009; Toutkoushian and Shafiq 2010). In recent years, state spending on higher education has fallen relative to other sources of revenue, 
and many publicly controlled universities have begun to rely primarily on other funding streams, such as tuition revenues and private giving (Ehrenberg 2006). As a result of these shifts, a number of scholars have begun to contemplate the implications of reduced state support for public colleges and universities (Feeney and Welch 2012; Fryar 2012). Given the complex nature of drawing public/private distinctions, we employ two models. The first includes the percentage of revenues from stable sources ${ }^{4}$ that institutions received in state appropriations and in grants and contracts from state governments, and the second uses a dichotomous measure for public or private control. All data on institutional finances come from IPEDS.

We also include an interactive term in our models between partisanship (percentage of Republicans in the state legislature and a dummy variable for Republican governor) and our variables for publicness (percentage of revenues from state government or public control), as institutions that are more reliant on state governments for financial support are likely to be more responsive to these political actors. To ease interpretation of these interaction terms, we have mean centered both legislative partisanship and the percentage of revenues from state governments.

\section{Controls}

Previous work on policy diffusion suggests that when organizations learn about policies adopted elsewhere by similar organizations, they may seek to adopt such policies in an effort to defend and/or improve their own performance (Shipan and Volden 2008). This reasoning is also supported by the idea that, over time, organizations will become more alike through isomorphic tendencies (DiMaggio and Powell 1983). Given that research universities often compete with other institutions in nearby states on a variety of dimensions related to prestige and reputation that are difficult to measure objectively, we expect that these organizations are highly responsive 
to isomorphic pressures with respect to organizational structure and design (Boxenbaum and Jonsson 2008) and include a measure for the number of universities in each region of the US that adopted or had previously adopted RCM in the prior year. We use the IPEDS classification of regions (New England, Mid East, Great Lakes, Plains, Southeast, Southwest, Rocky Mountains, Far West) to code this variable.

We also control for the overall size of the university (total number of undergraduate students), the fiscal health of the institution (total revenue per enrollment), and the demographic makeup of the student body (percentage of undergraduate students who are Black and percentage of undergraduate students who are Hispanic). Additionally, some previous research on RCM has indicated that these reforms are often most attractive for institutions and units that focus heavily on STEM fields (Hearn et al. 2006; Hearn and Gorbunov 2005), which have been in high demand in recent years. We include measures for whether the institution operates a hospital or medical center as well as the percentage of undergraduate degrees conferred that are in STEM fields, both of which we expect to be positively related to the likelihood of RCM adoption. All of the above variables were collected from IPEDS.

Next, we include faculty unionization, as this may have an impact on the ability of institutions to easily adopt and implement reforms such as RCM. We coded universities as having unionized faculty when a collective bargaining agency for full-time tenure track faculty in the institution was initially recognized. For purposes of this analysis, we only consider unionization of full-time tenure-track faculty and do not code institutions as being unionized if only staff or adjunct/temporary faculty have collective bargaining organizations. We use a report by the National Center for the Study of Collective Bargaining in Higher Education and the Professions (Berry and Savarese 2012) to identify institution-years with unionized faculty. 
Finally, we include a dichotomous measure for centralized governing boards, which previous research has found to influence a range of issues related to governance and higher education policy (Knott and Payne 2004). This data comes from the National Center for Higher Education Management Systems database for postsecondary governance structures (NCHEMS 2016).

\section{Evaluating the Impacts of RCM on Institutional Performance}

Despite the growing popularity of RCM among practitioners, little, if any, research has systematically assessed its effect on organizational performance. The second portion of our analysis draws on several outcome indicators using IPEDS data to evaluate the effects of RCM on performance in higher education. The time-series cross-sectional design of our dataset (with repeated observations for universities over time) allows us to compare performance of institutions prior to adoption of RCM with their performance after RCM has been implemented.

We examine two indicators of student outcomes that are central in recent discussions of performance in higher education: graduation rates and degree production. While other indicators of performance (such as financial performance in terms of revenues or cost efficiency, see Willett 2013) are also important, graduation rates and degree production are the most commonly used measures of performance in performance funding and other accountability policies for institutions in higher education and are highly salient for both university administrators and state policymakers (Hillman, Tandberg, and Fryar 2015; Rabovsky 2012). Graduation rates are measured as the percentage of first-time full-time students who graduate in six years or less ( $150 \%$ of normal time). Given that some have raised concerns about potential disparities related to RCM as it relates to certain degree programs and student populations (Hearn and Gorbunov 2005), we also include separate models for graduation rates by race/ethnicity. For the racial 
subgroup models we restrict the analysis to institutions that have at least 10 students in a cohort for a given racial/ethnic subgroup, as the dependent variable is highly sensitive to slight changes in completions in with very small cohort sizes. For example, institutions are only included in the models for Black graduation rate for years when they have at least 10 Black students in a cohort. As a result, the $\mathrm{N}$ size for each of the graduation rate models is slightly different, as some institutions have very few minority students in various cohorts. Similarly, we evaluate the impact of RCM on overall bachelor's degree production, as well as bachelor degree production within both STEM and humanities degree programs. We focus on STEM and humanities degrees because of potential tensions between these two umbrella fields and because the CIP codes associated with these programs have been clearly defined by the National Science Foundation (future work might consider completions in areas within these subfields such as business and health).

To control for other factors that have been found to affect college completion (Titus 2009; Zhang 2009), we include several independent variables such as student demographics, faculty characteristics, size, selectivity, institutional finances, and external variables related to governance structures and the political environment. For student demographics, we include the percentage of undergraduate students who are Black and who are Hispanic as well as the percentage of undergraduate students who enroll as part-time students. We also include a measure for the total number of undergraduate students (in thousands) to measure overall size, and a variable for the percentage of students who are undergraduates. We use Barron's classification of institutional selectivity, which is based on a combination of SAT/ACT scores and high school GPA, to control for important differences in student quality. Next, given that previous research has found that reliance on part-time and adjunct faculty are negatively related 
to student outcomes (Eagan and Jaeger 2008), we include a measure for the percentage of faculty in the institution who are full-time employees. Finally, we include total revenues per student as well as the percentage of revenues from the state government to capture elements related to institutional finance and capacity. ${ }^{5}$

With regards to the external environment, we include dichotomous measures for centralized governing boards and the presence of a statewide performance based funding policy. As was the case with our adoption models, we code the performance funding policy variable as zero for all private institutions. Finally, we also include measures for state partisanship in the legislature and governor, which previous research has found to affect a wide variety of issues related to higher education policy and performance (McLendon, Hearn, and Deaton 2006).

\section{Methodology}

To model the adoption of RCM in stage one of our analysis, we employ Cox regression models with time-varying independent variables (Box-Steffensmeier and Jones 2004), which has been widely used within the literature on diffusion and innovation (Jensen 2003; Ritchey and Nicholson-Crotty 2015). The basic premise of this approach is to estimate the relationship between each of the independent variables in the regression model and the likelihood (hazard) that some event will occur (in this case, that a university adopts RCM). As is common with survival analysis, institutions are dropped from the dataset once they have adopted RCM, and we use the Efron method to deal with ties where multiple institutions adopt RCM in the same year (Box-Steffensmeier and Jones 2004). Data for our adoption models cover the years 1986 to 2013.

The second part of our analysis evaluates the impacts of RCM on the performance of US colleges and universities. As is the case with adoption, our dataset has a time-series crosssectional (TSCS) design, with repeated observations for universities over several years (thus the 
units of analysis are university-years). Data for our outcomes models cover the years 1991 to 2009 for institutional graduation rates and 1991 to 2013 for degree production. We use linear regression with fixed effects for both institutions and years to address potential problems related to autocorrelation and time-trends that are common in this type of data. Given our use of institutional fixed effects, we are unable to estimate effects related to time-invariant factors such as flagship status or designation as a Historically Black College or University.

\section{Findings - Adoption}

Table 4 displays the hazard ratios and standard errors from our Cox regression models for the adoption of RCM. For hazard ratios, values greater than one indicate that an independent variable increases the likelihood of adoption while values less than one indicate that the variable makes adoption less likely. Models 1 and 2 show specifications that use the continuous measure of reliance on state funding while Models 3 and 4 include a dichotomous measure for public control.

\section{$<<<$ Insert Table 4 About Here $>>>$}

The two sets of models are substantively identical, and several notable findings emerge from our analysis. Most importantly, we find mixed evidence regarding our hypotheses for adoption. While neither of the base terms for partisanship, the percentage of legislators who are Republican and Republican governor, or reliance on state funding/public control (H1A or H2) are statistically significant (Models 1 and 3), the interaction terms for percentage of state legislators who are Republican and state funding/public control are positive and significant (Models 2 and 4). This indicates that institutions that rely heavily on state funding (or that are publicly controlled in the second set of results) are more likely to adopt RCM when they are located in states with more Republican state legislatures, all else equal. Thus, as the legislature 
becomes more Republican, institutions, particularly those that are more financially reliant on the state, may be under greater pressure to adopt market-based reforms like RCM.

We find no effect for a performance funding policy in the state (H1B). Given that much of the existing research suggests that performance funding has had a limited influence on institutional finances or performance (Hillman, Tandberg, and Fryar 2015; Rabovsky 2012; Rutherford and Rabovsky 2014), these results are not necessarily surprising. It should be noted, however, that performance funding policies continue to evolve; if future efforts are more effective in shaping institutional behavior, they may also generate stronger responses in terms of internal management reforms such as RCM.

Next, contrary to our expectations regarding isomorphic pressures and adoption of RCM, we find no effect for regional diffusion. One possible explanation for our lack of findings regarding isomorphism is that many institutions in our dataset may identify and respond to a set of peer and competitor organizations that are not within a specific geographic region. For instance, many elite public and private institutions view themselves as global leaders in higher education and may be most responsive to and form networks with other elite institutions that are dispersed across the country as opposed to strictly focusing on other institutions in their state or geographic region. We also find no statistically significant effects of faculty unionization on RCM adoption. One possible explanation is that faculty themselves may be divided on RCM, depending on their perceptions of how their own units or departments stand to gain or lose as a result of decentralized budgeting. It may also be that the relationship goes in some other direction such that RCM influences whether faculty consider whether to unionize.

In terms of other institutional characteristics, we find no effects related to the racial composition of the student body (percent Black, percent Hispanic) or total revenues per student. 
We do find a positive relationship between enrollment and the likelihood of adopting RCM. Similarly, we find that institutions that operate a hospital or medical center are more likely to adopt RCM. Both results are consistent with previous research and our expectations.

\section{Findings - RCM and Institutional Performance}

Turning to our findings regarding the impact of RCM on institutional performance, results for graduation rates are presented in Table 5, and models for degree completion are listed in Table 6. As previously mentioned, all models include both institution and year fixed effects. Here, we focus our discussion of the results on our key independent variable.

\section{$<<<$ Insert Table 5 About Here $>>>$}

With regards to the effect of RCM on graduation rates, we find mixed evidence that these reforms have clear positive effects. The coefficient is positive and significant for both overall graduation rates $(\beta=1.30)$ and graduation rates for white students $(\beta=1.719)$ but is not meaningful for either Black or Hispanic students. The coefficient is positive, though not statistically significant, for Hispanic students and is negative and insignificant for Black students. Despite the fact that the magnitudes of these effects are relatively small—approximately 0.07 and 0.08 standard deviations respectively - they are substantively meaningful given the heightened salience of institutional graduation rates in recent years. While these findings suggest some movement towards a higher level of efficiency, that some are better off while none are significantly worse off, we believe this finding also raises concerns about the equity of majority and minority student groups given that white students are already advantaged in many ways (see, for example, additional discussion related to welfare economics in Little 2002).

While we are not able to test the micro-level causal mechanisms that result in differential effects of RCM across demographic groups directly, one possibility is that institutions with RCM 
may invest more heavily in degree programs where Black and Hispanic students are underrepresented, which include STEM fields. This may especially be the case given that the results in Table 4 show that institutions operating a hospital or medical unit are more likely to adopt RCM. Alternatively, it could be that RCM causes the incentive structures for academic units within the university to be oriented primarily towards admissions and enrollments. Because tuition and student fees are the primary way that actors within these units can generate revenues to pay for operational strategies that expand their programs, there might be fewer incentives to invest heavily in advising, counseling, or other programs that focus on improving outcomes for traditionally under-represented or disadvantaged populations. At the very least, our results suggest the need for further research to explore the potential linkage between RCM and student equity.

In terms of other notable findings regarding graduation rates, we draw attention to both our measure of publicness (percentage of revenues from state government) and the partisanship of the state legislature. For the former, we find that increased reliance on state funding is positively associated with Black graduation rates $(\beta=0.104)$. Similarly, the percentage of state legislators who are Republican is negatively associated with graduation rates for Black students $(\beta=-0.103)$, but is positively related to graduation rates for White students $(\beta=0.028)$, while Republican governor is not statistically significant for any of the models. Finally, we note that the coefficient for statewide performance funding policy fails to achieve statistical significance in any of our models, which is consistent with previous research on these policies (Hillman, Tandberg, and Fryar 2015; Rutherford and Rabovsky 2014)

$<<<$ Insert Table 6 About Here $>>$ 
The findings for degree production tell a story similar to the graduation rate models. We find no statistically significant relationship between RCM and overall degree production or degree production within humanities programs, though it should be noted that the coefficient for RCM in the humanities degree production model is negative, but we do find a positive effect for production of STEM degrees $(\beta=3.047)$. As was the case in our graduation rate models, the magnitude of this effect is somewhat limited (approximately 0.08 standard deviations), so the substantive impact of RCM does not appear to be very large on average. These findings again raise questions related to the potential for RCM to create winners and losers within the institution, particularly in exploring whether this outcome presents some unintended consequences.

Finally, we also considered the fact that there may be implementation time dynamics such that effects on student outcomes differ as institutions have greater experience with RCM. As a robustness check, we broke RCM implementation up by length of time: no RCM at all, new RCM policy that has been in place between 1 and 3 years, and established RCM policy that has been in place for longer than 3 years; different time categories or a simple count measure did not improve the models. The results were mostly consistent with the findings reported above, and the adjusted R-squares are also similar. This suggests we do not gain much additional explanatory power from splitting up RCM by length of policy. One important exception was some evidence that Hispanic graduation rates improve as institutions have an established (3 or more years) RCM policy. A possible driver of the similarity of results for the dichotomous variable and a more nuanced measure that accounts for time dynamics is that many institutions have adopted RCM within the last decade, making it difficult to assess the long-term effects until more data becomes available. Thus, this is clearly an area where more research is needed in the years to come. 


\section{Discussion}

The purpose of this research was to investigate the causes and consequences of marketbased policies that organizations adopt internally. Overall, some of our hypotheses were supported more strongly than others. In the adoption models in Table 4, a more nuanced relationship was detected for our main adoption hypotheses; the share of Republican legislators was linked to slightly higher adoption hazard rates for institutions that are more dependent on the state for funding. This highlights that the degree of publicness in these institutions can have markedly different meanings for institutions given the larger political environment and what party holds majority power in the state. It is also important to note that when these institutions do not rely on state appropriations heavily, policymakers - whether Republican or Democrathave little influence, at least in terms of the RCM.

Tables 5 and 6 also revealed some interesting relationships related to the effect of RCM policies. While no evidence was generated to show that these policies have a direct negative effect on students or degree production (H3) and some evidence was provided for the positive effects of RCM (H4) through overall graduation rates and STEM degrees, these gains raised important questions related to equity (H5). In this sample, we find that while the policy losers may not lose when measuring change in their own absolute levels of performance, they stand to lose relative to the gains experienced by other groups. We argue this can create disconcerting gaps in outcomes, especially for students, though there is much debate about whether one should focus on absolute or relative gains and losses. Black and Hispanic students already have graduation rates that lag behind their White peers; this system may widen the gap by helping the students who have the lowest levels of need. Degree production processes are not entirely unrelated to this phenomenon. Minority students are more likely to be in non-STEM programs, 
and these programs do not experience any change in outputs while their STEM counterparts experience some level of success. As such, it may be the case that institutions are attempting to implement these programs without hurting individual student equity, but the fact that students sort themselves into different types of programs such that minority groups are underrepresented in fields that gain from RCM should not be dismissed.

In light of the effects of RCM detected in this study, there is a need for more in-depth research on the implementation processes and effects of internally adopted market-based strategies with large $\mathrm{N}$ data. We find there that such programs do not relate to negative outcomes as clearly as some externally imposed programs. That said, we cannot confidently tout the positive and significant coefficients without pausing to consider issues of equity in these institutions. Specific to this study, there are a variety of decision-making processes that RCM might influence but which we cannot adequately examine with current IPEDS data that are aggregated to the level of the institution. Part of the issue may be that RCM improves performance in some areas of the organization while hampering performance in others, and it is difficult to get at such trade-offs in a clean way in terms of measurement with existing data. The findings for both graduation rates and degree production are both suggestive of such a process in terms of creating winners and losers. In many ways, this could be intended by design to reward high performing units; however, it can also result in some categories of winners and losers that are problematic when considering how student sort into majors.

Additionally, there are a multitude of ways that RCM could potentially improve performance that cannot be captured here. For instance, RCM may encourage units to adopt reforms that are more consumer oriented-in this case more responsive to student concerns. RCM might also cause units within the institution to engage in strategic planning efforts that 
help them to differentiate their degree programs and academic offerings from other units on campus as well as from other colleges and universities. All of these things could be important in terms of helping the institution, or at least some units within the institution, improve along dimensions related customer satisfaction, financial health, or institutional reputation.

\section{Conclusion}

Market-based strategies like RCM might work in some cases but are not likely to be appropriate for all organizations, especially given factors of the larger political climate, make-up of the clientele-base, and the presence of a market for specific services. Practically, different specific policy design decisions (e.g., how to allocate revenues and expenses) likely produce slightly different results. In some cases, it may be less clear how common standards, shared values, and horizontal collaboration can be balanced with ideals of decentralization, innovation, and competition (see a similar discussion for the case of whole-of-government initiations in Christensen and Lægreid $(2001,2007)$. Certainly from our collection of RCM data, organizations are often looking to one another for advice and feedback on policy design, implementation, and taxes for centralized expenditures. Administrators can use the findings of this study to consider how various policy designs may be more or less appropriate for their organizations.

It should also be noted that there are a variety of both cognitive and physical costs that accompany major reorganization strategies such as RCM, so the question of whether this type of change is ultimately worth such an investment is important. An examination of the costs associated with adoption and implementation of RCM was outside the scope of this study, but future research on this topic should explore such issues to provide a more complete understanding regarding potential pitfalls and payoffs for decentralization. 
Theoretically, this study shows that internally adopted market-based strategies do not lead to a direct negative effect, which in some cases is better than externally imposed policies. However, more work is required to determine how and why these policies may work and what can be done to avoid unintended consequences that may pit efficiency against equity. The results of this study should also be replicated in other policy areas to determine if similar causes and effects are detected such that a larger framework can be considered. In the meantime, caution of such market approaches will likely continue. 


\section{Notes}

1. This self-driven initiative may not always be entirely separable from external pressures. For example, part of the reason that managers may adopt a new system could be because of the pressures surrounding their organization.

2. Of course, it is possible that managers might try to impress various stakeholder groups with an internal reform which could result in the defining of performance indicators and goals that are most convenient for the organization (e.g., Staw and Epstein 2000). While we cannot eliminate this possibility, we argue that the costs of reforms are high enough such that managers are likely to adopt standards they believe will have some positive effect on organizational performance.

3. Harvard University has employed a similar model of budgeting dating back at least to the $19^{\text {th }}$ century known as "every tub on its own bottom," though there is disagreement as to whether this model is consistent with more modern RCM approaches. For the purposes of our analysis on adoption, we drop Harvard from our dataset. Additionally, data for our independent variables only cover the years 1986-2013, so our Cox regression models are unable to capture adoptions prior to 1986.

4. As defined by IPEDS, stable sources of revenue include state appropriations, state grants and contracts, federal appropriations, federal grants and contracts (minus money received for Pell grants), net revenue from tuition, and private gifts, grants and contracts. The primary reason for using this measure rather than total revenue is that it excludes investments, for which several institutions took significant losses during the 2008 financial crisis. As a result of these losses, many of these institutions report negative total revenues for some years, making 
total revenues problematic to use in the denominator for our measure of reliance on funding from state government.

5. Total revenues include income from all sources, including tuition, government grants, contracts, and appropriations, private donations, investments, and endowments. Because of losses on investments— particularly during the 2008 recession-some institutions have negative values for total revenues for some years. As a result, we use this variable for overall institutional financial condition but calculate on state government using measure for stable revenues described in the previous section to calculate reliance 


\section{References}

Andrews, Matthew, and Herb Hill. 2003. "The Impact of Traditional Budgeting Systems on the Effectiveness of Performance-Based Budgeting: A Different Viewpoint on Recent Findings.” International Journal of Public Administration 26(2): 135-55.

Behn, Robert D. 2002. “The Psychological Barriers to Performance Management: Or Why Isn't Everyone Jumping on the Performance-Management Bandwagon?” Public Performance \& Management Review 26(1): 5-25.

Berry, Joe, and Michelle Savarese. 2012. Directory of U.S. Faculty Contracts and Bargaining Agents in Institutions of Higher Education. National Center for the Study of Collective Bargaining in Higher Education and the Professions. https://www.insidehighered.com/sites/default/server_files/files/facdirectory.pdf.

Bevan, Gwyn, and Christopher Hood. 2006. "What's Measured Is What Matters: Targets and Gaming in the English Public Health Care System.” Public Administration 84(3): 51738.

Bohte, John, and Kenneth J. Meier. 2000. “Goal Displacement: Assessing the Motivation for Organizational Cheating.” Public Administration Review 60(2): 173-82.

Boxenbaum, Eva, and Stefan Jonsson. 2008. "Isomorphism, Diffusion and Decoupling.” In The SAGE Handbook of Organizational Institutionalism, eds. Royston Greenwood, Christine Oliver, Roy Suddaby, and Kerstin Sahin. Thousand Oaks, CA: SAGE, 78-98.

Box-Steffensmeier, Janet M., and Bradford S. Jones. 2004. Event History Modeling: A Guide for Social Scientists. Cambridge ; New York: Cambridge University Press.

Boyne, George A. 2004. “A ‘3Rs' Strategy for Public Service Turnaround: Retrenchment, Repositioning and Reorganization.” Public Money \& Management 24(2): 97-103. 
Brudney, Jeffrey L., F. Ted Hebert, and Deil S. Wright. 1999. "Reinventing Government in the American States: Measuring and Explaining Administrative Reform.” Public Administration Review 59(1): 19-30.

Christensen, Tom, and Per Lægreid. 2001. "New Public Management: The Effects of Contractualism and Devolution on Political Control." Public Management Review 3(1): 73-94.

, eds. 2007. Transcending New Public Management: The Transformation of Public Sector Reforms. Aldershot, England: Ashgate.

Cullen, Julie Berry, and Randall Reback. 2006. Tinkering Toward Accolades: School Gaming Under a Performance Accountability System. National Bureau of Economic Research. Working Paper. http://www.nber.org/papers/w12286 (May 5, 2016).

Damanpour, Fariborz, Richard M. Walker, and Claudia N. Avellaneda. 2009. “Combinative Effects of Innovation Types and Organizational Performance: A Longitudinal Study of Service Organizations.” Journal of Management Studies 46(4): 650-75.

Darling-Hammond, Linda. 1994. "Performance-Based Assessment and Educational Equity." Harvard Educational Review 64(1): 5-31.

Diamond, John, and James Spillane. 2004. "High-Stakes Accountability in Urban Elementary Schools: Challenging or Reproducing Inequality?" The Teachers College Record 106(6): $1145-1176$.

DiMaggio, Paul J., and Walter W. Powell. 1983. “The Iron Cage Revisited: Institutional Isomorphism and Collective Rationality in Organizational Fields.” American Sociological Review 48(2): 147-60. 
Eagan, M. Kevin, and Audrey J. Jaeger. 2008. "Effects of Exposure to Part-Time Faculty on Community College Transfer." Research in Higher Education 50(2): 168-88.

Ehrenberg, Ronald G., ed. 2006. What's Happening to Public Education? Westport, CT: Praeger Publishers.

Feeney, Mary K., and Eric W. Welch. 2012. "Realized Publicness at Public and Private Research Universities." Public Administration Review 72(2): 272-284.

Fernandez, Sergio, and David W. Pitts. 2007. “Under What Conditions Do Public Managers Favor and Pursue Organizational Change?" The American Review of Public Administration 37(3): 324-41.

Fernandez, Sergio, and Hal G Rainey. 2006. "Managing Successful Organizational Change in the Public Sector.” Public Administration Review 66(2): 168-76.

Fryar, Alisa Hicklin. 2012. “What Do We Mean by Privatization in Higher Education?” In Higher Education: Handbook of Theory and Research, Higher Education: Handbook of Theory and Research, eds. John C. Smart and Michael B. Paulsen. Springer Netherlands, $521-47$.

Gayle, Dennis John, Bhoendradatt Tewarie, and Quiinton A. White Jr. 2003. Governance in the Twenty-First-Century University: Approaches to Effective Leadership and Strategic Management: ASHE-ERIC Higher Education Report. Washington, D.C: ERIC.

Hart, David K. 1972. "Theories of Government Related to Decentralization and Citizen Participation." Public Administration Review 32: 603-21.

Hearn, James C. et al. 2006. “'Incentives for Managed Growth': A Case Study of IncentivesBased Planning and Budgeting in a Large Public Research University." The Journal of Higher Education 77(2): 286-316. 
Hearn, James C., and Alexander V. Gorbunov. 2005. "Funding the Core: Understanding the Financial Contexts of Academic Departments in the Humanities." In Tracking Changes in the Humanities: Essays on Finance and Education, ed. Malcolm Richardson. Cambidge, MA: American Adacemy of Arts and Sciences, 1-45.

Heinrich, Carolyn J. 2002. “Outcomes-Based Performance Management in the Public Sector: Implications for Government Accountability and Effectiveness.” Public Administration Review 62(6): 712-25.

Hillman, Nicholas W., David A. Tandberg, and Alisa H. Fryar. 2015. "Evaluating the Impacts of 'New' Performance Funding in Higher Education." Educational Evaluation and Policy Analysis 37(4): 501-19.

Jensen, Jason L. 2003. "Policy Diffusion through Institutional Legitimation: State Lotteries." Journal of Public Administration Research and Theory 13(4): 521-41.

Kaufman, Herbert. 1969. “Administrative Decentralization and Political Power.” Public Administration Review 29(1): 3-15.

Klarner, Carl. 2016. “State Partisan Balance Data, 1937-2015.” http://klarnerpolitics.com/kpdataset-page.html.

Knott, Jack H., and A. Abigail Payne. 2004. "The Impact of State Governance Structures on Management and Performance of Public Organizations: A Study of Higher Education Institutions." Journal of Policy Analysis and Management 23(1): 13-30.

Koch, Ray, Kevin Reynolds, and Monica Rimai. 2012. "Winter Symposium.” http://www.pdx.edu/oaa/sites/www.pdx.edu.oaa/files/FINAL\%202012\%20Winter\%20Sy mposium\%20Slides.ppt. 
de Lancer Julnes, Patria, and Marc Holzer. 2001. "Promoting the Utilization of Performance Measures in Public Organizations: An Empirical Study of Factors Affecting Adoption and Implementation.” Public Administration Review 61(6): 693-708.

Little, Ian Malcolm David. 2002. A Critique of Welfare Economics. Oxford: Oxford University Press.

McLendon, Michael K., James C. Hearn, and Steven B. Deaton. 2006. "Called to Account: Analyzing the Origins and Spread of State Performance-Accountability Policies for Higher Education." Educational Evaluation and Policy Analysis 28(1): 1-24.

McLendon, Michael K., Christine G. Mokher, and William R. Doyle. 2009. “'Privileging' Public Research Universities: An Empirical Analysis of the Distribution of State Appropriations across Research and Non-Research Universities." Journal of Education Finance 34(4): $372-401$.

Mitchell, Michael, Vincent Palacios, and Michael Leachman. 2014. States Are Still Funding Higher Education Below Pre-Recession Levels. Washington, D.C: Center on Budget and Policy Priorities. http://www.cbpp.org/research/states-are-still-funding-higher-educationbelow-pre-recession-levels.

Morphew, Christopher C., and Peter D Eckel, eds. 2009. Privatizing the Public University: Perspectives from Across the Academy. Johns Hopkins University Press.

Moynihan, Donald P. 2008. The Dynamics of Performance Management. Washington, DC: Georgetown University Press.

Moynihan, Donald P., and Sanjay K. Pandey. 2010. “The Big Question for Performance Management: Why Do Managers Use Performance Information?” Journal of Public Administration Research and Theory 20(4): 849-66. 
Nakamura, Robert T. 1987. "The Textbook Policy Process and Implementation Research.” Review of Policy Research 7(1): 142-54.

NCHEMS. 2016. Postsecondary Governance Structures Database. Boulder, CO: National Center for Higher Education Management Systems. http://www.nchems.org/psgov/ (October 25, 2016).

NCSL. 2015. Performance-Based Funding for Higher Education. Denver, Co: National Conference of State Legislatures. http://www.ncsl.org/research/education/performancefunding.aspx.

Nielsen, Poul A. 2014. “Learning from Performance Feedback: Performance Information, Aspiration Levels, and Managerial Priorities." Public Administration 92(1): 142-60.

Poister, Theodore H. 2003. Measuring Performance in Public and Nonprofit Organizations. San Francisco: Jossey-Bass.

Pollitt, Christopher. 2002. “The New Public Management in International Perspective.” In New Public Management: Current Trends and Future Prospects, eds. Kathleen McLaughlin, Stephen P. Osborne, and Ewan Ferlie. New York, NY: Routledge, 274.

Rabovsky, Thomas M. 2012. “Accountability in Higher Education: Exploring Impacts on State Budgets and Institutional Spending Patterns.” The Journal of Public Administration Research and Theory 22(4): 675-700.

—. 2014. "Using Data to Manage for Performance at Public Universities." Public Administration Review 74(2): 260-72.

Radin, Beryl A. 2006. Challenging the Performance Movement: Accountability, Complexity, and Democratic Values. Washington, DC: Georgetown University Press. 
Ritchey, Mark, and Sean Nicholson-Crotty. 2015. “'Blue Ribbon' Commissions, Interest Groups, and the Formulation of Policy in the American States.” Policy Studies Journal 43(1): 7092.

Rourke, Francis E. 1992. "Responsiveness and Neutral Competence in American Bureaucracy." Public Administration Review 52(6): 539-46.

Rutherford, Amanda. 2014. “Organizational Turnaround and Educational Performance The Impact of Performance-Based Monitoring Analysis Systems.” The American Review of Public Administration 44(4): 440-58.

Rutherford, Amanda, and Thomas Rabovsky. 2014. "Evaluating Impacts of Performance Funding Policies on Student Outcomes in Higher Education.” The ANNALS of the American Academy of Political and Social Science 655(1): 185-208.

Sabatier, Paul A., and Christopher Weible. 2014. Theories of the Policy Process. 3rd ed. Boulder, CO: Westview Press.

Schick, Allen. 2001. “Getting Performance Measures to Measure Up.” In Quicker, Better, Cheaper? Managing Performance in American Government, ed. Dan Forsythe. Albany, NY: Rockefeller Institute Press, 39-60.

Shipan, Charles R., and Craig Volden. 2008. "The Mechanisms of Policy Diffusion.” American Journal of Political Science 52(4): 840-57.

Simon, Herbert A. 1946. "The Proverbs of Administration.” Public Administration Review 6(1): $53-67$.

Soss, Joe, Richard Fording, and Sanford F. Schram. 2011. "The Organization of Discipline: From Performance Management to Perversity and Punishment.” Journal of Public Administration Research and Theory 21(Supplement 2): i203-32. 
Speklé, Roland F., and Frank H. M. Verbeeten. 2014. "The Use of Performance Measurement Systems in the Public Sector: Effects on Performance.” Management Accounting Research 25(2): 131-46.

Staw, Barry M., and Lisa D. Epstein. 2000. "What Bandwagons Bring: Effects of Popular Management Techniques on Corporate Performance, Reputation, and CEO Pay." Administrative Science Quarterly 45(3): 523-56.

Strauss, Jon C., and John R. Curry. 2002. Responsibility Center Management: Lessons from 25 Years of Decentralized Management. Anapolis, MD: National Association of College and University Business Officials.

Strauss, Jon C., John R. Curry, and Edward L. Whalen. 1996. "Revenue Responsibility Budgeting." In Resource Allocation in Higher Education, ed. William F. Massey. Ann Arbor, MI: University of Michigan Press, 163-90.

Syracuse University. 2014. Senate Committee on Budget and Fiscal Affairs (SBC) Report Part II - Continuing Challenges. http://universitysenate.syr.edu/wpcontent/uploads/2014/04/cme_budget_rpt_2014-04-16.pdf.

van Thiel, Sandra, and Frans L. Leeuw. 2002. "The Performance Paradox in the Public Sector." Public Performance \& Management Review 25(3): 267-81.

Titus, Marvin A. 2009. “The Production of Bachelor's Degrees and Financial Aspects of State Higher Education Policy: A Dynamic Analysis." The Journal of Higher Education 80(4): $439-68$.

Toutkoushian, Robert K., and M. Najeeb Shafiq. 2010. “A Conceptual Analysis of State Support for Higher Education: Appropriations Versus Need-Based Financial Aid." Research in Higher Education 51(1): 40-64. 
University of Arizona. N.D. Responsibility Centered Management Models at Other Universities. http://provost.arizona.edu/files/R\%20C\%20M\%20Models.pdf.

Van Dooren, Wouter. 2008. "Nothing New Under the Sun? Change and Continuity in Performance Movements." In Performance Information in the Public Sector: How It Is Used, eds. Wouter Van Dooren and Steven Van De Walle. Houndmills, UK: Palgrave, $11-23$.

Walker, Richard M., Fariborz Damanpour, and Carlos A. Devece. 2011. "Management Innovation and Organizational Performance: The Mediating Effect of Performance Management." Journal of Public Administration Research and Theory 21(2): 367-86.

Whalen, Edward L. 1991. Responsibility Center Budgeting: An Approach to Decentralized Management for Institutions of Higher Education. Bloomington, IN: Indiana University Press.

Willett, Michael S. 2013. "Effects of an Incentive Based Budgeting System on Institutional Performance Indicators: An Exploratory Longitudinal Case Study of a Public University.” Doctoral Dissertation. Indiana University.

Zhang, Liang. 2009. "Does State Funding Affect Graduation Rates at Public Four-Year Colleges and Universities?" Educational Policy 23(5): 714-31. 
Table 1 - Summary Statistics for RCM Adoption (1986-2013)

\begin{tabular}{lcccc}
\hline & Mean & SD & Min & Max \\
\hline \% Revenues from State Government & 33.02 & 25.31 & 0.00 & 87.78 \\
\% State Legis. Republicans & 44.76 & 14.08 & 5.17 & 88.57 \\
Republican Governor & 0.56 & 0.50 & 0.00 & 1.00 \\
Statewide Performance Funding Policy & 0.10 & 0.30 & 0.00 & 1.00 \\
Unionized Faculty & 0.17 & 0.38 & 0.00 & 1.00 \\
Centralized Governing Board & 0.28 & 0.45 & 0.00 & 1.00 \\
Undergrad. Enrollment (in 1,000s) & 12.41 & 9.19 & 0.01 & 70.89 \\
\% Students Black & 10.77 & 16.59 & 0.00 & 99.82 \\
\% Students Hispanic & 6.73 & 10.06 & 0.00 & 82.51 \\
University Operates a Hospital or Medical Center & 0.14 & 0.34 & 0.00 & 1.00 \\
Revenues Per Student (in constant \$1000s) & 45.33 & 90.74 & -454.06 & 1503.87 \\
\% Undergraduate Degrees Awarded in STEM Fields & 22.48 & 17.35 & 0.00 & 100.00 \\
\hline
\end{tabular}


Table 2 - Summary Statistics for Institutional Performance (1991-2013)

\begin{tabular}{lcccc}
\hline & Mean & SD & Min & Max \\
\hline RCM & 0.06 & 0.24 & 0 & 1 \\
Graduation Rates (All Races) & 59.89 & 18.84 & 1.93 & 100 \\
Graduation Rates (White) & 61.03 & 19.62 & 0 & 100 \\
Graduation Rates (Black) & 49.32 & 21.17 & 0 & 100 \\
Graduation Rates (Hispanic) & 53.64 & 21.91 & 0 & 100 \\
Total Bachelor's Degrees Per 1,000 Undergrad Enrollment & 195.12 & 45.54 & 37.30 & 590.71 \\
Stem Degrees Per 1,000 Undergraduate Enrollment & 45.12 & 36.47 & 0 & 261.64 \\
Humanities Degrees Per 1,000 Undergrad. Enrollment & 30 & 20.32 & 0 & 187.84 \\
Unionized Faculty & 0.17 & 0.38 & 0 & 1 \\
\% Students Black & 10.98 & 16.55 & 0 & 99.82 \\
\% Students Hispanic & 7.16 & 10.27 & 0 & 82.51 \\
In-State Tuition and Fees (constant \$1000s) & 13.73 & 11.92 & 0 & 49.14 \\
\% Undergraduate & 71.29 & 13.85 & 3.75 & 100 \\
Undergrad. Enrollment (in 1,000s) & 13.15 & 9.36 & 0.16 & 70.89 \\
\% of Students Part-Time & 25.31 & 14.38 & 0.08 & 83.57 \\
\% Faculty Full-Time & 72.55 & 18.40 & 6.70 & 100 \\
\% Funding from State Government & 31.75 & 24.06 & 0 & 84.17 \\
Revenues Per Student (in constant \$1000s) & 45.40 & 55.87 & -429.37 & 673.55 \\
Selectivity (Barron's) & 3.67 & 1.27 & 0 & 6 \\
Statewide Performance Funding Policy & 0.12 & 0.33 & 0 & 1 \\
Centralized Governing Board & 0.28 & 0.45 & 0 & 1 \\
\% State Legis. Republicans & 46.52 & 13.79 & 8.85 & 88.57 \\
Republican Governor & 0.57 & 0.49 & 0 & 1 \\
\hline
\end{tabular}


Table 3 - US Institutions of Higher Education Adopting RCM

\begin{tabular}{|c|c|}
\hline Name of Institution & Year Adopted RCM \\
\hline University of Pennsylvania & 1974 \\
\hline Vanderbilt University & 1980 \\
\hline University of Southern California & 1982 \\
\hline Johns Hopkins University* & 1987 \\
\hline Clemson University & 1989 \\
\hline Indiana University-Purdue University-Indianapolis & 1989 \\
\hline Indiana University & 1990 \\
\hline Duke University & 1991 \\
\hline University of Pittsburgh-Pittsburgh Campus & 1992 \\
\hline American University & 1996 \\
\hline Claremont Graduate University & 1996 \\
\hline Rensselaer Polytechnic Institute & 1997 \\
\hline University of California-Los Angeles & 1997 \\
\hline University of Minnesota-Twin Cities & 1997 \\
\hline Central Michigan University & 1998 \\
\hline University of Michigan-Ann Arbor & 1998 \\
\hline University of Illinois at Urbana-Champaign & 1999 \\
\hline University of New Hampshire-Main Campus & 2000 \\
\hline University of Idaho & 2001 \\
\hline Ohio State University-Main Campus & 2003 \\
\hline Syracuse University & 2007 \\
\hline University of Illinois at Chicago & 2007 \\
\hline Illinois Institute of Technology & 2008 \\
\hline Iowa State University & 2009 \\
\hline Kent State University at Kent & 2009 \\
\hline Northeastern University & 2011 \\
\hline Pace University-New York & 2011 \\
\hline University of Florida & 2011 \\
\hline University of Oregon & 2011 \\
\hline University of California-Davis & 2012 \\
\hline University of Delaware & 2012 \\
\hline Emory University & 2013 \\
\hline University of South Dakota & 2013 \\
\hline
\end{tabular}

*We found conflicting reports for the RCM adoption date for Johns Hopkins University. We have coded RCM as starting in 1987 (the earliest date that there is consensus about RCM being in place) for the purposes of our analysis. 
Table 4 - Adoption of RCM (1986-2013)

\begin{tabular}{|c|c|c|c|c|}
\hline & (1) & (2) & (3) & (4) \\
\hline \% State Legis. Republicans (Mean Centered) & $\begin{array}{c}1.005 \\
(0.276)\end{array}$ & $\begin{array}{c}1.009 \\
(0.508)\end{array}$ & $\begin{array}{c}1.005 \\
(0.320)\end{array}$ & $\begin{array}{c}0.966 \\
(-1.232)\end{array}$ \\
\hline Republican Governor & $\begin{array}{c}0.653 \\
(-1.018)\end{array}$ & $\begin{array}{c}0.655 \\
(-0.950)\end{array}$ & $\begin{array}{c}0.660 \\
(-0.992)\end{array}$ & $\begin{array}{c}0.641 \\
(-0.572)\end{array}$ \\
\hline$\%$ Revenues from State Gov (Mean Centered) & $\begin{array}{c}0.990 \\
(-1.030)\end{array}$ & $\begin{array}{c}0.980 \\
(-1.433)\end{array}$ & & \\
\hline$\%$ Rev. from State $* \%$ Repub. Legislature & & $\begin{array}{c}\mathbf{1 . 0 0 1}^{+} \\
(\mathbf{1 . 7 8 2})\end{array}$ & & \\
\hline$\%$ Rev. from State * Republican Governor & & $\begin{array}{c}1.023 \\
(1.211)\end{array}$ & & \\
\hline Public Institution & & & $\begin{array}{c}0.872 \\
(-0.244)\end{array}$ & $\begin{array}{c}1.066 \\
(0.086)\end{array}$ \\
\hline Public *\% Repub. Legislature & & & & $\begin{array}{l}\mathbf{1 . 0 6 5}^{+} \\
(\mathbf{1 . 7 5 6 )}\end{array}$ \\
\hline Public * Republican Governor & & & & $\begin{array}{c}0.971 \\
(-0.032)\end{array}$ \\
\hline Statewide Performance Funding Policy & $\begin{array}{c}1.016 \\
(0.023)\end{array}$ & $\begin{array}{c}0.987 \\
(-0.019)\end{array}$ & $\begin{array}{c}0.936 \\
(-0.096)\end{array}$ & $\begin{array}{c}0.745 \\
(-0.415)\end{array}$ \\
\hline Regional Diffusion of RCM & $\begin{array}{c}1.050 \\
(0.467)\end{array}$ & $\begin{array}{c}1.105 \\
(0.894)\end{array}$ & $\begin{array}{c}1.061 \\
(0.565)\end{array}$ & $\begin{array}{c}1.110 \\
(0.953)\end{array}$ \\
\hline Unionized Faculty & $\begin{array}{c}1.685 \\
(1.015)\end{array}$ & $\begin{array}{c}1.734 \\
(1.058)\end{array}$ & $\begin{array}{c}1.454 \\
(0.729)\end{array}$ & $\begin{array}{c}1.449 \\
(0.720)\end{array}$ \\
\hline Centralized Governing Board & $\begin{array}{c}1.282 \\
(0.488)\end{array}$ & $\begin{array}{c}1.138 \\
(0.239)\end{array}$ & $\begin{array}{c}1.171 \\
(0.312)\end{array}$ & $\begin{array}{c}1.055 \\
(0.100)\end{array}$ \\
\hline Undergrad. Enrollment (in 1,000s) & $\begin{array}{l}1.034^{*} \\
(2.329)\end{array}$ & $\begin{array}{l}\mathbf{1 . 0 3 8}^{*} \\
(\mathbf{2 . 5 2 1})\end{array}$ & $\begin{array}{l}\mathbf{1 . 0 3 3}^{+} \\
(1.916)\end{array}$ & $\begin{array}{l}\mathbf{1 . 0 2 9}^{+} \\
(1.721)\end{array}$ \\
\hline$\%$ Students Black & $\begin{array}{c}0.936 \\
(-1.420)\end{array}$ & $\begin{array}{c}0.939 \\
(-1.337)\end{array}$ & $\begin{array}{c}0.934 \\
(-1.486)\end{array}$ & $\begin{array}{c}0.936 \\
(-1.431)\end{array}$ \\
\hline$\%$ Students Hispanic & $\begin{array}{c}0.975 \\
(-0.745)\end{array}$ & $\begin{array}{c}0.973 \\
(-0.763)\end{array}$ & $\begin{array}{c}0.974 \\
(-0.788)\end{array}$ & $\begin{array}{c}0.979 \\
(-0.641)\end{array}$ \\
\hline University Operates a Hospital or Medical Center & $\begin{array}{l}\mathbf{3 . 1 4 9}^{* * *} \\
(\mathbf{2 . 6 3 5})\end{array}$ & $\begin{array}{l}\text { 3.535** } \\
(\mathbf{2 . 8 4 3})\end{array}$ & $\begin{array}{l}\mathbf{3 . 0 3 4}^{*} \\
(\mathbf{2 . 5 7 0})\end{array}$ & $\begin{array}{l}\text { 3.236** } \\
\text { (2.699) }\end{array}$ \\
\hline Revenues Per Student (in constant $\$ 1000$ s) & $\begin{array}{c}1.000 \\
(-0.108)\end{array}$ & $\begin{array}{c}1.000 \\
(-0.179)\end{array}$ & $\begin{array}{c}1.000 \\
(0.032)\end{array}$ & $\begin{array}{c}1.000 \\
(0.009)\end{array}$ \\
\hline \% Undergrad Degrees Awarded in STEM Fields & $\begin{array}{c}1.017 \\
(1.511)\end{array}$ & $\begin{array}{c}1.017 \\
(1.478)\end{array}$ & $\begin{array}{c}1.016 \\
(1.409)\end{array}$ & $\begin{array}{c}1.015 \\
(1.308)\end{array}$ \\
\hline Observations & 6851 & 6851 & 6852 & 6852 \\
\hline Log li & -141.405 & -138.185 & -141.914 & -140.138 \\
\hline Chi-squared & 24.667 & 31.106 & 23.657 & 27.209 \\
\hline
\end{tabular}

Hazard Ratios; $z$ statistics in parentheses

${ }^{+} p<0.10,{ }^{*} p<0.05,{ }^{* *} p<0.01,{ }^{* * * *} p<0.001$ 
Table 5 - Graduation Rates (1991-2009)

\begin{tabular}{|c|c|c|c|c|}
\hline & $\begin{array}{l}\text { Graduation Rates } \\
\text { (All Races) }\end{array}$ & $\begin{array}{c}\text { Graduation Rates } \\
\text { (White) }\end{array}$ & $\begin{array}{c}\text { Graduation Rates } \\
\text { (Black) }\end{array}$ & $\begin{array}{c}\text { Graduation Rates } \\
\text { (Hispanic) }\end{array}$ \\
\hline \multirow[t]{2}{*}{$\mathrm{RCM}$} & $1.300^{*}$ & $1.719^{* * *}$ & -0.803 & 1.964 \\
\hline & $(\mathbf{0 . 5 9})$ & $(0.67)$ & $(1.19)$ & $(1.20)$ \\
\hline \multirow[t]{2}{*}{ Unionized Faculty } & -0.575 & 0.107 & -3.389 & 1.350 \\
\hline & $(0.87)$ & $(0.98)$ & $(2.08)$ & $(1.90)$ \\
\hline \multirow[t]{2}{*}{$\%$ Students Black } & $-0.348^{* * * *}$ & $-0.242^{* * * *}$ & $-0.506^{* * * *}$ & $-0.613^{* * * *}$ \\
\hline & $(0.04)$ & $(0.04)$ & $(\mathbf{0 . 0 7})$ & $(0.09)$ \\
\hline \multirow[t]{2}{*}{$\%$ Students Hispanic } & $0.194^{* * * *}$ & $0.122^{*}$ & $0.317^{* * *}$ & -0.034 \\
\hline & $(\mathbf{0 . 0 5})$ & $(0.06)$ & $(0.10)$ & $(0.11)$ \\
\hline \multirow[t]{2}{*}{ In-State Tuition and Fees (const. $\$ 1000$ s) } & $-0.233^{* * * *}$ & $-0.333^{* * * *}$ & $-0.235^{* *}$ & $-0.293^{* * * *}$ \\
\hline & $(0.04)$ & $(0.04)$ & $(\mathbf{0 . 0 8 )}$ & $(\mathbf{0 . 0 8})$ \\
\hline \multirow[t]{2}{*}{$\%$ Undergraduate } & $-\mathbf{0 . 1 0 3} 3^{* * * *}$ & -0.040 & -0.069 & -0.078 \\
\hline & $(\mathbf{0 . 0 2})$ & $(0.02)$ & $(0.05)$ & $(0.06)$ \\
\hline \multirow[t]{2}{*}{ Undergrad. Enrollment (in 1,000s) } & $0.107^{*}$ & -0.081 & $0.438^{* * * *}$ & -0.070 \\
\hline & $(\mathbf{0 . 0 5})$ & $(0.06)$ & (0.11) & $(0.12)$ \\
\hline \multirow[t]{2}{*}{$\%$ of Students Part-Time } & $-0.085^{* * * *}$ & -0.019 & $-0.123^{* * * *}$ & $-0.112^{* * *}$ \\
\hline & $(\mathbf{0 . 0 2})$ & $(0.02)$ & $(\mathbf{0 . 0 4})$ & $(0.04)$ \\
\hline \multirow[t]{2}{*}{$\%$ Faculty Full-Time } & $0.019^{* *}$ & $\mathbf{0 . 0 1 3}^{+}$ & 0.015 & 0.009 \\
\hline & $(0.01)$ & $(\mathbf{0 . 0 1})$ & $(0.01)$ & $(0.02)$ \\
\hline \multirow[t]{2}{*}{$\%$ Funding from State Government } & 0.011 & $-0.026^{+}$ & $0.104^{* * * *}$ & -0.040 \\
\hline & $(0.01)$ & $(\mathbf{0 . 0 1})$ & $(\mathbf{0 . 0 3})$ & $(0.03)$ \\
\hline \multirow[t]{2}{*}{ Rev. Per Student (const. \$1000s) } & -0.001 & -0.001 & -0.000 & -0.001 \\
\hline & $(0.00)$ & $(0.00)$ & $(0.00)$ & $(0.00)$ \\
\hline \multirow[t]{2}{*}{ Selectivity (Barron's) } & $1.566^{* * * *}$ & $1.300^{* * * *}$ & $1.471^{* * * *}$ & $0.911^{* * * *}$ \\
\hline & $(\mathbf{0 . 1 2})$ & $(0.14)$ & $(0.24)$ & $(0.26)$ \\
\hline \multirow[t]{2}{*}{ Statewide Performance Funding Policy } & 0.201 & 0.056 & 0.104 & -0.186 \\
\hline & $(0.29)$ & $(0.33)$ & $(0.57)$ & $(0.61)$ \\
\hline \multirow{2}{*}{ Centralized Governing Board } & $2.723^{* *}$ & 3.379** & $8.694^{* * * *}$ & -2.272 \\
\hline & $(\mathbf{1 . 0 5})$ & (1.18) & $(2.34)$ & $(2.52)$ \\
\hline \multirow{2}{*}{$\%$ State Legis. Republicans } & -0.011 & $0.028^{*}$ & $-0.103^{* * * *}$ & -0.041 \\
\hline & $(0.01)$ & $(0.01)$ & $(0.02)$ & $(0.03)$ \\
\hline
\end{tabular}




\begin{tabular}{|c|c|c|c|c|}
\hline Republican Governor & -0.041 & -0.056 & 0.034 & 0.105 \\
\hline Constant & $\begin{array}{c}(0.15) \\
\mathbf{6 7 . 6 0 6}^{\text {***** }} \\
(\mathbf{2 . 2 5})\end{array}$ & $\begin{array}{c}(0.17) \\
\mathbf{6 6 . 3 8 3}^{* * *} \\
(\mathbf{2 . 5 7})\end{array}$ & $\begin{array}{c}(0.29) \\
\mathbf{5 5 . 1 3 8}^{* * * *} \\
(\mathbf{4 . 7 3 )}\end{array}$ & $\begin{array}{c}(0.32) \\
\mathbf{7 6 . 1 1 6}^{* * * *} \\
(\mathbf{5 . 6 8})\end{array}$ \\
\hline Observations & 4388 & 4289 & 4070 & 3871 \\
\hline Adjusted $R^{2}$ & 0.397 & 0.345 & 0.219 & 0.189 \\
\hline
\end{tabular}

Standard errors in parentheses

${ }^{+} p<0.10,{ }^{*} p<0.05,{ }^{* *} p<0.01,{ }^{* * *} p<0.001$ 
Table 6 - Degree Production (1991-2013)

\begin{tabular}{|c|c|c|c|}
\hline & $\begin{array}{c}\text { Total Bachelor's Degrees } \\
\text { Per 1,000 Undergraduate } \\
\text { Enrollment }\end{array}$ & $\begin{array}{c}\text { Stem Degrees Per 1,000 } \\
\text { Undergraduate } \\
\text { Enrollment }\end{array}$ & $\begin{array}{c}\text { Humanities Degrees Per } \\
\text { 1,000 Undergraduate } \\
\text { Enrollment }\end{array}$ \\
\hline $\mathrm{RCM}$ & $\begin{array}{l}2.969 \\
(2.12)\end{array}$ & $\begin{array}{c}3.047^{* * *} \\
(1.10)\end{array}$ & $\begin{array}{l}-0.398 \\
(0.75)\end{array}$ \\
\hline Unionized Faculty & $\begin{array}{l}-2.677 \\
(3.32)\end{array}$ & $\begin{array}{l}0.798 \\
(1.73)\end{array}$ & $\begin{array}{l}0.890 \\
(1.17)\end{array}$ \\
\hline$\%$ Students Black & $\begin{array}{c}-1.345^{* * *} \\
(0.14)\end{array}$ & $\begin{array}{r}-0.155^{*} \\
(0.07)\end{array}$ & $\begin{array}{c}-0.160^{* * * *} \\
(0.05)\end{array}$ \\
\hline$\%$ Students Hispanic & $\begin{array}{c}\mathbf{0 . 7 2 8}^{* * * *} \\
(0.16)\end{array}$ & $\begin{array}{c}0.294^{* * * *} \\
(0.08)\end{array}$ & $\begin{array}{c}0.416^{* * * *} \\
(0.06)\end{array}$ \\
\hline In-State Tuition and Fees (const. \$1000s) & $\begin{array}{c}-0.773^{\text {*** }} \\
(0.13)\end{array}$ & $\begin{array}{l}-0.031 \\
(0.07)\end{array}$ & $\begin{array}{c}-0.522^{* * * *} \\
(0.05)\end{array}$ \\
\hline$\%$ Undergraduate & $\begin{array}{c}-0.756^{* * * *} \\
(0.08)\end{array}$ & $\begin{array}{c}-0.503^{* * * *} \\
(0.04)\end{array}$ & $\begin{array}{c}0.237^{* * * *} \\
(\mathbf{0 . 0 3})\end{array}$ \\
\hline Undergrad. Enrollment (in 1,000s) & $\begin{array}{c}-1.414^{* * * *} \\
(0.18)\end{array}$ & $\begin{array}{l}-0.135 \\
(0.09)\end{array}$ & $\begin{array}{c}-0.622^{* * * *} \\
(0.06)\end{array}$ \\
\hline$\%$ of Students Part-Time & $\begin{array}{c}-0.575^{* * * *} \\
(0.06)\end{array}$ & $\begin{array}{c}-0.204^{* * * *} \\
(0.03)\end{array}$ & $\begin{array}{c}-0.073^{* * * *} \\
(0.02)\end{array}$ \\
\hline$\%$ Faculty Full-Time & $\begin{array}{l}0.069^{*} \\
(0.03)\end{array}$ & $\begin{array}{c}\mathbf{0 . 0 8 0}^{* * * *} \\
(\mathbf{0 . 0 2})\end{array}$ & $\begin{array}{r}-0.025^{*} \\
(0.01)\end{array}$ \\
\hline$\%$ Funding from State Government & $\begin{array}{c}-0.159^{* * * *} \\
(0.05)\end{array}$ & $\begin{array}{c}-0.084^{* * * *} \\
(0.02)\end{array}$ & $\begin{array}{c}-0.098^{* * * *} \\
(0.02)\end{array}$ \\
\hline Revenues Per Student (const \$1000s) & $\begin{array}{l}0.005 \\
(0.01)\end{array}$ & $\begin{array}{l}\mathbf{0 . 0 1 0}^{+} \\
(0.01)\end{array}$ & $\begin{array}{c}-0.017^{* * * *} \\
(0.00)\end{array}$ \\
\hline Selectivity (Barron's) & $\begin{array}{c}1.912^{* * * *} \\
(0.51)\end{array}$ & $\begin{array}{l}0.597^{*} \\
(0.27)\end{array}$ & $\begin{array}{c}1.268^{* * * *} \\
(0.18)\end{array}$ \\
\hline Statewide Performance Funding Policy & $\begin{array}{l}0.628 \\
(1.12)\end{array}$ & $\begin{array}{l}0.428 \\
(0.58)\end{array}$ & $\begin{array}{l}0.424 \\
(0.39)\end{array}$ \\
\hline Centralized Governing Board & $\begin{array}{l}\text { 7.049 }^{+} \\
(4.03)\end{array}$ & $\begin{array}{l}1.655 \\
(2.10)\end{array}$ & $\begin{array}{l}1.131 \\
(1.42)\end{array}$ \\
\hline$\%$ State Legis. Republicans & $0.076^{+}$ & 0.026 & $0.044^{* *}$ \\
\hline
\end{tabular}




\begin{tabular}{|c|c|c|c|}
\hline \multirow{3}{*}{ Republican Governor } & $(0.05)$ & $(0.02)$ & $(0.02)$ \\
\hline & -0.215 & $-0.640^{*}$ & 0.020 \\
\hline & $(0.62)$ & $(\mathbf{0 . 3 2})$ & $(0.22)$ \\
\hline Constant & $\begin{array}{c}287.683^{* * * *} \\
(8.66)\end{array}$ & $\begin{array}{c}82.047^{\text {**** }} \\
(4.51)\end{array}$ & $\begin{array}{c}28.240^{\text {**** }} \\
(3.04)\end{array}$ \\
\hline Observations & 5787 & 5787 & 5787 \\
\hline Adjusted $R^{2}$ & 0.166 & 0.072 & 0.072 \\
\hline
\end{tabular}

${ }^{+} p<0.10,{ }^{*} p<0.05,{ }^{* *} p<0.01,{ }^{* * * *} p<0.001$ 